\title{
THE PERCEPTION SURVEY OF BUILDINGS BASED ON WOOD IN THE CONTEXT OF TRADITIONAL CONSTRUCTION METHODS
}

\author{
Ing. Švajlenka J ozef; prof. Ing. Kozlovská Mária, Ph.D.
}

\begin{abstract}
In the context of using modern methods of construction in Slovakia seem to be the most widespread building systems prefabricated buildings based on wood. Modern wooden buildings are undoubtedly constructions that realize the most modern and innovative construction methods. Modern buildings based on wood are becoming increasingly popular and more popular also in Slovakia. Even despite undeniable advantages that are associated with the use of modern construction systems based on wood, preventing more widespread wooden buildings low level of knowledge and awareness on the part of customers and investors. The aim of the paper is to present the lessons learned of realized socio economic survey on the perception properties of buildings based on wood in the context of traditional methods of construction through potential users. Obtaining information through questioning of respondents was carried out personal interviews as well as an electronic on-line questionnaire. The questionnaire was composed of five parts. The first part focuses on data about the respondent, others parts are focused on the architectural, constructional and technical, social, technological and economic oriented issues.
\end{abstract}

Key words: modern methods of construction, construction based on wood, socio-economic research

\section{INTRODUCTION}

Contemporary modern wooden buildings by Vaverka et al. [1] are undoubtedly constructions which are constructed with the most modern and most innovative construction methods. Their advantage is speed of construction, high quality, simple project management, transparent costs and the use of existing modern technologies in construction, which is also supported several foreign and domestic studies $[2-4,10]$. They are becoming increasingly popular and more popular not only in Europe but also in Slovakia. This is evidenced by the increasing number share of new buildings based on wood in Slovakia. According to the Association of Wood Processors Slovak Republic [6] for the last ten years has increased the share of modern wooden buildings in individual housing construction in Slovakia twice and is about $10 \%$. For comparison with other countries, this proportion is still very small. In Europe, the representation of wooden substantially (70\% Scandinavia, Germany 50\%, Austria 45\%, $20 \%$ Czech, USA 65\%, Canada 80\%, England 40\%). Even despite undeniable advantages that are associated with the use of modern construction systems based on wood by Štefko [9] prevents more widespread wooden buildings in Slovakia low level of knowledge and awareness on the part of customers and investors as strong ties to traditional masonry technology.

To enhance the general awareness about public opinion in Slovakia, we have undertaken a socioeconomic survey on the knowledge of modern structural prefabricated construction system based on wood. A similar survey dealing with several different analyzes of the potential of modern methods of construction within the framework of research aimed at increasing the efficiency of construction by means of MMC technology on Faculty of Civil Engineering at the Technical University of Košice [14, 17-19]. Similar themes dealt with in the years 2013-2015, several research works in the Czech Republic at the Mendel University in Brno [15, 16]. The work has focused on user satisfaction wooden 
houses in different regions of the Czech Republic. They focused primarily on the views of users on the advantages and disadvantages of wooden, method of realization, the choice of heating medium and what criteria are opting for realization wooden buildings.

\section{THE RESEARCH METHODOLOGY AND DISCUSSION}

The aim of realized socio economic survey was to map the survey of potential users on the barriers and benefits of prefabricated buildings of wood based in Slovakia. Acquisition of information was carried out during 2014 in the form of questioning of respondents personal interviews as well as an electronic on-line questionnaire. The questionnaire included a total of 16 questions disaggregated into five parts. The first part focuses on data about the respondent, other parts are focused on the architectural, constructional and technical, social and techno-economically oriented issues. It was obtained by interviewing a total of more than 120 responses to the questionnaire. Of the respondents mostly higher and secondary education was $55.3 \%$ of men and $44.7 \%$ women. For the age group 1825 years is represented $10.6 \%$ were aged $26-35$ years was $33.3 \%$, at age $36-45$ years was $22 \%$ and over the age of 45 years was $34.1 \%$ of respondents. Most respondents came from Eastern Slovakia in the ratio of $57.7 \%$ of the total, were from Central Slovakia was $13 \%$ and Western Slovakia was $29.3 \%$ of respondents.

\subsection{Survey of architectural parameters}

In the part focused on architectural issues corresponds to $62.6 \%$ of respondents have heard of the prefabricated construction based on wood, $34.1 \%$ heard something about the construction of prefabricated wood-based but do not know exactly what system it is, and only $4 \%$ of respondents have heard of this construction system. For these statements that the overwhelming majority of respondents know the system or the realization of such a construction system met. Respondents opinions on limiting and limits to the use only of regular shapes in the architectural design of prefabricated buildings of wood-based, is largely inclined to the view that construction assembled systems are not limited to regular shapes (53.7\%), $35.8 \%$ of respondents think that they are limited only partially and $10.6 \%$ think that they are limited to regular shapes construction. On question of how the architectural appearance would prefer for buildings (in general), $61 \%$ of respondents prefer combined shapes, $24.4 \%$ of respondents prefer modern, cubic shapes, and only $14.6 \%$ preferred shapes with added bevelled planes (walls at different angles, sloping roof areas, etc.).

\subsection{Survey of constructional and technical parameters}

In the constructional and technical related issues for more than $43 \%$ of respondents believe that the use of a wide range of material in the design of prefabricated of realization based on wood (layers of flooring, cladding, filling openings, roof deck...) is certainly not limited compared to traditional systems of construction. Slightly fewer respondents (38\%) were the opinion that the restrictions are only partial and $19 \%$ think that the prefabricated structural systems based on wood have limited material range compared to traditional construction system, which may be due to the very naming structure (wooden building). More than $76 \%$ of respondents adhering to the view that the prefabricated buildings based on wood are capable of achieving low-energy standard. About $20 \%$ think that it is possible to achieve this standard only under certain conditions and only less than $4 \%$ were considered low-energy standard that is not achievable through the implementation of prefabricated buildings of wood-based (Fig. 1). In terms of stability of the building nearly $70 \%$ of respondents think that prefabricated buildings based on wood are comparable with the structures of traditional systems and practically not limited in the number of floors and even $2.4 \%$ of respondents believe that the stability of such structures is higher. 


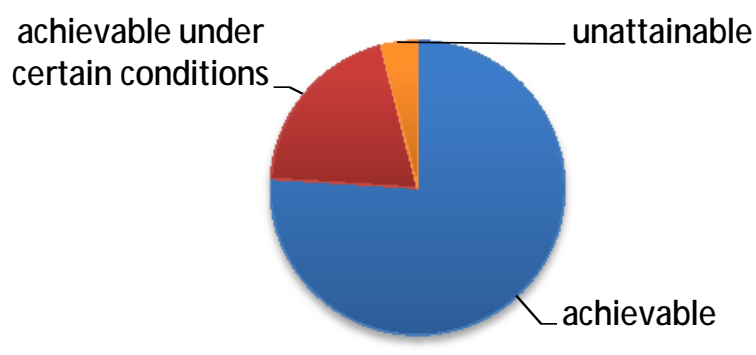

Fig. 1 View of respondents achieving to the low-energy standard in comparison with structures of traditional systems.

\subsection{Survey of social parameters}

Socially oriented issues related to respondents views of interior comfort wooden buildings (thermal comfort, sound insulation, sufficient light, adequate internal air humidity). Nearly $80 \%$ of respondents answered that the assembled structure of wood-based interior comfort can be achieved compared to traditional systems of construction. Around 17\% were of the opinion that it is possible to achieve an internal comfort, but at the expense of high cost and only 3.3\% think that desired comfort cannot be achieved (Fig. 2).

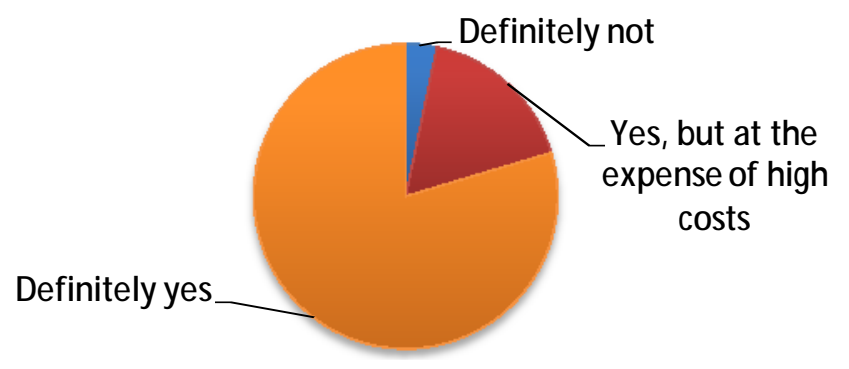

Fig. 2 View of respondents to achieve the internal comfort of prefabricated buildings of wood-based compared with structures of traditional systems.

The question focused on the using of wooden constructions for different purposes, the largest percentage of respondents agreed on family houses as well as the additional building or superstructure, which proves that the respondents who already have property, when it would consider the reconstruction of the system. Around 50\% of respondents see the potential in construction of schools, nursery, dormitories, and administrative office space (Fig. 3). The lowest representations of using wooden buildings see in buildings for health care.

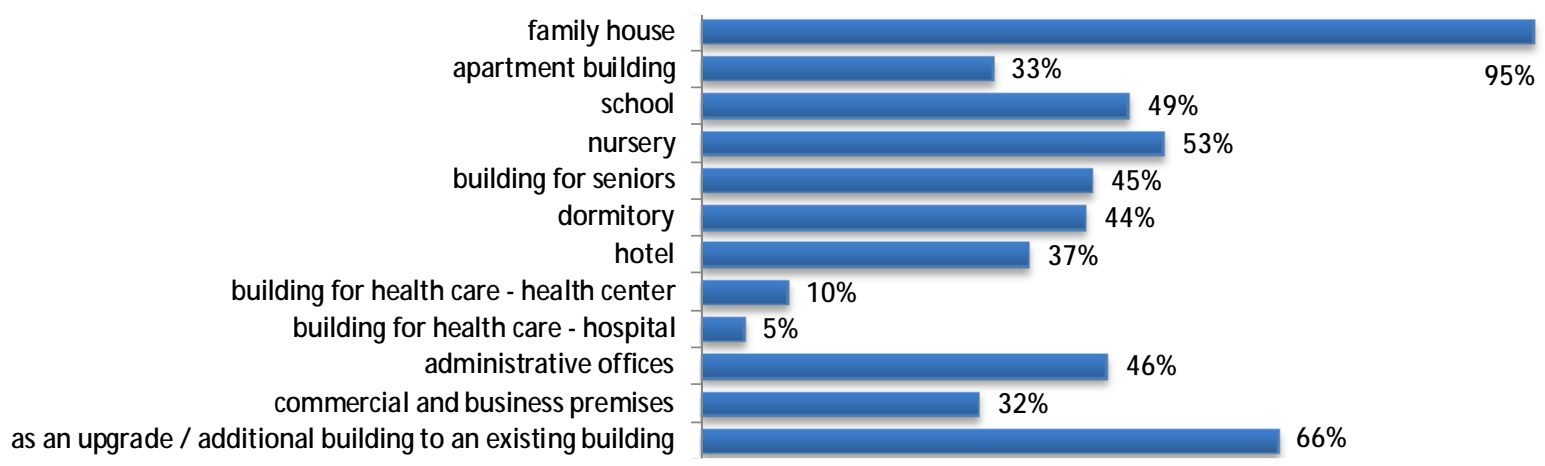

Fig. 3 View of respondents on most proper structures to implemented through the use of prefabricated buildings of wood-based. 


\subsection{Survey of technological and economic parameters}

Technological and economic oriented issues related parameters of the construction time and the quality of buildings, declared as the main advantages wooden buildings. Three-quarters of respondents were the opinion that the realized time prefabricated buildings based on wood are compared with structures of traditional systems less. $17 \%$ think that the execution time is almost the same and $7 \%$ said that the realized time is longer (Fig. 4). In doing so shortening the realized time is the biggest advantage of wooden buildings, as they are realized by dry method of realization, which allows almost immediate and seamless use of the building. In terms of the quality of realization $61 \%$ of respondents said that the quality of implementation of prefabricated buildings of wood-based is compared with structures of traditional systems almost the same, $33 \%$ of respondents felt that the quality is better and $6 \%$ of respondents have opinion that the quality of such buildings is even worse (Fig. 5).

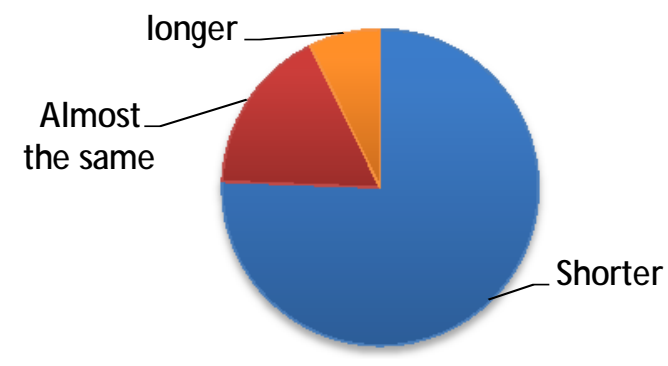

Fig. 4 View of respondents on the period of realization of prefabricated buildings of wood-based compared with structures of traditional systems.

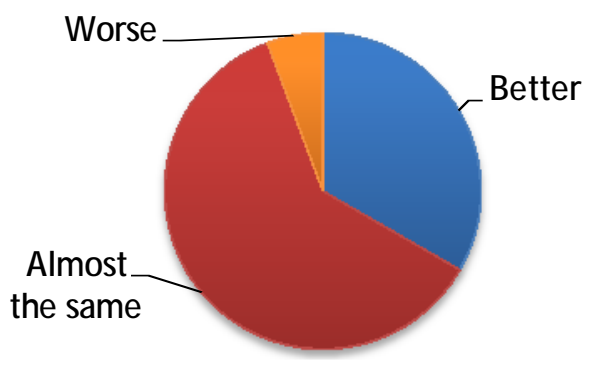

Fig. 5 View of respondents on the quality of realization of prefabricated buildings of wood-based compared with structures of traditional systems.

Last issues has focused on the notion of respondents compared to the costs of procuring and the use wooden buildings compared to traditional systems (Fig. 6). Most respondents believe that the costs for project documentation are comparable but almost one third believe they are above. In doing so the actual cost of the project documentation are almost identical in comparison with traditional systems projects for construction. More than half of respondents believe that the costs for realization of the wooden buildings are lower, more than a one quarter of them deems they are comparable and almost a fifth thought that the costs to implement wooden buildings are higher. Diversity of opinion confirms that it is those costs are different due to the type of construction, location, contractor, and so on. This parameter cannot be precisely evaluated as an advantage compared to traditional wooden buildings system construction. In the area of operating costs to use wooden buildings absolute majority of respondents assimilated the view that the operating costs are lower, but $6 \%$ of the respondents was that the cost to use the above. It should be noted that at present all new buildings are required to have over existing buildings lower operating costs, due to the valid legislation on thermal insulation in buildings.

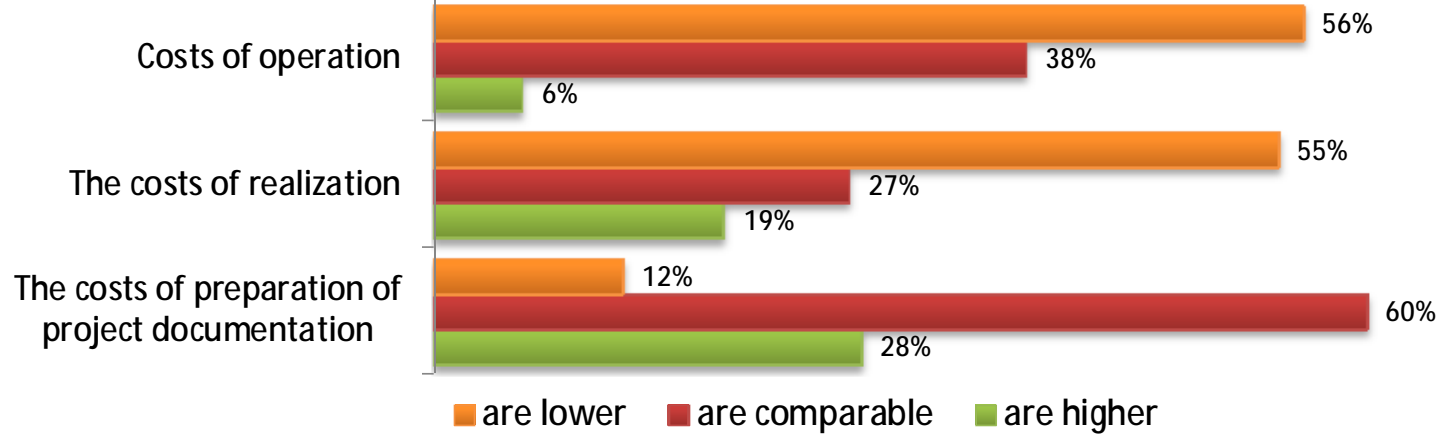

Fig. 6 View of respondents on the comparison of costs of prefabricated buildings of wood-based systems with traditional construction. 


\section{CONCLUSION}

The present socio-economic research provides an analysis of how they perceived potential users of modern prefabricated structural systems based on wood. Assessed the answers of respondents pointed to the fulfilment of the declared performance of wooden buildings, such as Thermal requirements of applicable standards and laws which is related to low operating costs for use of the building, maintaining the required quality and carrying capacity in a shorter period of realization to which they relate lower costs of realization and the impact of realization to the surrounding environment. Potential users in the vast majority also perceive that the concept of wooden construction is not limited to the use of wood, but also the choice of variable material and design solutions compared to traditional systems of construction. Thanks to the mentioned benefits, the awareness of potential users as expanding the information relating to wooden buildings as well as the benefits of these structural system, which is a prerequisite for increased interest of potential users of modern wooden houses.

\section{Acknowledgement}

The article presented a partial research result of project VEGA - 1/0677/14 "Research of construction efficiency improvement through MMC technologies"

\section{Literature}

[1] VAVERKA, J. - HAVÍŘ́VÁ, Z. - JINDRÁK, M. a kol.: Dřevostavby pro bydlení, GradaPublishing, a.s., Praha 2008, ISBN 978-80-247-2205-4.

[2] KOLB, J.: Dřevostavby, Vydavatel'stvo Grada Publishing, Praha 2008, ISBN 978-80-2472275-7.

[3] BURWOOD, S. - JESS, P.: Modern Methods of Construction Evolution or Revolution?, A BURA Steering and Development forum report, 2005, [cit. 2014-01-30], Online: $<$ http://www.buildicf.co.uk/pdfs/1\%20mmc\%20evolution\%20or\%20revolution\%20\%20paper. pdf $>$.

[4] SMITH, R., E. - TIMBERLAKE, J.: Prefab architecture: a guide to modular design and construction, Canada, 2011, ISBN 978-0-470-27561-0.

[5] Štatistický úrad SR: [cit 2014-12-02], Online: <http://portal.statistics.sk>.

[6] Zväz spracovatel’ov dreva Slovenskej republiky: Online: 〈http://www.zsdsr.sk/>.

[7] KUJANOVÁ, K., Drevostavby - Vieme o nich všetko?: [cit. 2014-01-10], Online: <http://www.domabyvanie.eu/page/index.php?log=clanok\&uid=44>.

[8] KUZMA, I.: Prečo si postavit' dom z dreva, [cit. 2014-01-10], Online: <http://mojdom.zoznam.sk/cl/100496/1353668/Preco-si-postavit-dom-z-dreva〉.

[9] ŠTEFKO, J. a kol.: Moderné drevostavby, Vydavatel'stvo ANTAR, Bratislava 2010, ISBN 80967718-9-2.

[10] KEMPTON, J.: Modern methods of construction: Maintenance issues in the registered social landlord sector, [cit. 2014-01-29], Online: <http://www.arcom.ac.uk/docs/proceedings/ar2009-0251-0260_Kempton.pdf>.

[11] Modern methods of construction: [cit. 2014-01-28], Online: $<$ http://www.concretecentre.com/technical_information/building_solutions/modern_methods_ of_construction.aspx $>$.

[12] KOZLOVSKÁ, M., SPIŠÁKOVÁ, M.: Nové technológie výstavby z pohl’adu znižovania odpadov. WASTE fórum, [cit. 2014-10-10], Online: <http://www.wasteforum.cz/cisla/WF_2_2013.pdf\#page=4>. 
[13] ČULÁKOVÁ, M.: Katalóg stavebných konštrukcií drevostavieb, 2013, [cit 2014-09-20], Online: <https://sites.google.com/site/hodnoteniebudov/home/katalog-stavebnych-konstrukciidrevostavieb>.

[14] KOZLOVSKÁ, M. - KALEJA, P. - STRUKOVÁ, Z.: Sustainable construction technology based on building modules, In: Advanced Materials Research. Vol. 1041, 2014, p. 231-234. ISSN 1022-6680.

[15] HAHN, P.: Marketingová studie spokojenosti uživatelů dřevostaveb ve Zlínském Kraji, Mendelova Univerzita v Brně, Fakulta regionálniho rozvoje a medzinárodních studií, Brno 2013.

[16] HLAVÁČ, T.: Marketingová studie spokojenosti uživatelů dřevostaveb na území středočeského kraje, Mendelova Univerzita vBrně, Lesnická a dřevařská fakulta, Brno 2015.

[17] MESÁROŠ, P. - MANDIČÁK, T. - KYJAKOVÁ, L.: Management of information flows in modern methods of construction, In: European International Journal of Applied Science and Technology. Vol. 1, no. 3 (2014), p. 51-61., ISSN 2372-8385.

[18] MAČKOVÁ, D. - SPIŠÁKOVÁ, M.: STEKO wood modular construction systém, In: Improving the efficiency of construction through MMC technologies : Proceedings of scientific papers 2014. - Košice : TU, 2014 S. 55-62. - ISBN 978-80-553-1885-1.

[19] KYJAKOVÁ, L. - BAŠKOVÁ, R.: Modern methods of foundations for modular constructions, In: Oceňovanie a riadenie stavebných projektov 2014 : Zborník vedeckých prác. - Brusel : EuroScientia vzw, 2014 P. 93-100. - ISBN 978-90-822990-1-4. 